\title{
Hadhanah Dalam Prespektif Imam Madhab dan Kompilasi Hukum Islam serta Pengaruhnya Terhadap Pendidikan Anak
}

\section{Hadhanah Dalam Prespektif Imam Madhab dan Kompilasi Hukum Islam serta Pengaruhnya Terhadap Pendidikan Anak}

\author{
Masadah \\ STIT Raden Wijaya Mojokerto \\ masadah789@gmail.com
}

\begin{abstract}
When a divorce occurs, then at that time created due to the law including the Hadhanah which is basically the responsibility of both parents who will be held accountable before God. Education is a human right which is part of economic, social and cultural rights. Likewise with a child, he has the right to obtain proper education from his parents. The pattern of hadhanah is very influential on a child's education. The house is an inseparable part of education because it starts from home. Every human being gets an initial education. Certainly, the real education provided by educators is parents in the form of care (educating). Therefore in this paper we elaborate on the hadhanah, legal basis, time, who is entitled and the conditions and how the provisions of the Hadhanah in the Compilation of Islamic Law and the Effects of Hadhanah on Children's Education. This paper is expected to provide benefits to the reader, especially for divorced couples where the child of divorce can grow psychologically as normal as other children.
\end{abstract}

Keywords: Radicalism, Aswaja Education.

\begin{abstract}
Abstrak
Ketika terjadi perceraian, maka pada saat itu tercipta akibat hukumnya diantaranya hadhanah yang mana pada dasarnya menjadi tanggung jawab kedua orang tua yang kelak akan di pertanggung jawabkan di hadapan Allah. Pendidikan merupakan salah satu hak asasi manusia yang merupakan bagian dari hak ekonomi, sosial dan budaya. Begitupun dengan seorang anak, ia berhak memperoleh pendidikan yang layak dari orang tuanya. Pola hadhanah sangat berpengaruh terhadap pendidikan seorang anak. Rumah merupakan bagian yang tidak bisa dipisahkan dari pendidikan karena bermula dari rumah setiap manusia mendapatkan pendidikan awal.Tentunya pendidikan secara rill yang diberikan oleh pendidik yaitu orangtua dalam bentuk pengasuhan (mendidik). Oleh karena itu dalam tulisan ini kami mengurai tentang hadhanah, dasar hukum, masa, siapa yang berhak dan syarat-syaratnya serta bagaimana ketentuan hadhanah dalam Kompilasi Hukum Islam dan Pengaruh Hadhanah terhadap pendidikan Anak. Tulisan ini diharapkan memberikan manfaat
\end{abstract}




\section{Mas'adah.}

bagi pembaca terutama bagi pasangan yang bercerai dimana anak korban perceraian dapat tumbuh normal secara psikologis sebagaimana anak anak lainnya

Kata Kunci: Hadzanah, Kompilasi Hukum Islam, .

\section{A. PENDAHULUAN}

Indonesia Diantara akibat hukum perceraian adalah mengenai hak asuh atas anak yang lahir dari perkawinan tersebut yang dikenal dengan istilah hadhanah ${ }^{1}$ yang diberikan kepada salah satu pihak suami atau isteri. Hadhanah ialah meletakkan sesuatu dekat tulang rusuk atau di pangkuan²"sehingga pengertian hadhanah tidak saja meliputi perawatan fisik namun juga pendidikan anak sejak dari lahir sampai sanggup mengurus dirinya sendiri. Di sisi lain hubungan anak dan orang tua, selamanya tidak akan pernah putus, sekalipun berpisah karena perceraian atau kematian. Agama telah mengatur tidak ada istilah mantan anak, atau mantan bapak, atau mantan ibu sekalipun berpisah karena perceraian atau kematian.

Sejatinya pemeliharaan anak adalah tanggung jawab kedua orang tua secara bersama ${ }^{3}$. Anak adalah pilar utama dalam pembangunan yang diamaanahkaan Allah untuk dijaga dan kelak akan dimintai pertanggung jawabannya. Oleh karena itu anak harus dijaga, dilindungi, diawasi, dan diberi pendidikan, bantuan, bimbingan, pengarahan, perlindungan dengan sebaik-baiknya.

1 Abd Rahman Ghazaly,Fiqih Muna\&ahat,(Jakarta:Prenada Media,2013),h 175 dan "Ibrahim Muhammad Al-Jamal, Fiqih Muslimah ,h 341.

${ }^{2}$ Sebagaimana ibu waktu menyusukan anaknya meletakkan anaknya di pangkuannya, seakan akan ibu di saat itu melindungi dan memelihara anaknyat lihat Sayyid Sabiq, Fiqih Sunnah, Jilid 2, (Jakarta: Pena Pundi Aksara,2007),hal, 37

${ }^{3}$ Sahl Mahfudz: Solusi Problematika Umat, (Surabaya: LTN NU Jawa Timur, 2003), hal. 309 


\section{Hadhanah Dalam Prespektif Imam Madhab dan Kompilasi Hukum Islam serta Pengaruhnya Terhadap Pendidikan Anak}

tidak bisa dianggap sebagai harta benda yang bisa diperlakukan sekehendak hati oleh orang tuanya agar anak tersebut bisa tumbuh dan berkembang dengan baik demi tercapainya generasi masa depan yang sholih, berakhlak, dan bermartabat.

Untuk mengatasi segala perseoalan yang terjadi tentang perebutan hak asuh anak pasca perceraian, pengetahuan serta hukum yang berlaku haruslah diketahui dan dipahami. penulis akan membahas mengenai "Hadhanah atau Hak Asuh Anak menurut Perspektif Imam Madzhab".

\section{B. METODOLOGI PENELITIAN}

Penelitian ini menggunakan jenis penelitian pustaka (library research), sedangkan sifat penelitian ini bersifat deskriptif komparatif, data dianalisis dengan menggunakan pendekatan kaidah yang menjadi pedoman (Normatif), agar hokum dapat dipahami dengan mudah, karena hokum agama diturunkan untuk kepentingan social.

Teknik pengumpulan data yang digunakan adalah penelaahan terhadap literature hokum Islam dan literature lainnya yang berkaitan dengan masalah yang diteliti, kemudian data-data tersebut akan diolah, yang selanjutnya akan dijadikan bahan utama untuk memenuhi target penelitian yang hendak dicapai. Dan analisis data menggunakan analisis secara kulaitatif.

C. .HASIL DAN PEMBAHASAN

1. Hak Pemeliharaan Anak Pasca Cerai 


\section{Mas'adah.}

Setelah terjadinya perceraian, maka ibu atau ayah wajib memelihara anaknya secara sendiri-sendiri ${ }^{4}$.Dan selama tidak ada hal yang menghalangi untuk memelihara anak-anak, maka ibulah yang harus melaksanakan hadhanah ${ }^{5}$. Para fuqaha' sepakat bahwa hak pemeliharaan anak (hadhanah) ada pada ibu' selama ia belum bersuami lagi7. Apabila ia telah bersuami lagi dan sudah disetubuhi oleh suami yang baru maka gugurlah pemeliharaannya. ${ }^{8}$ Sedangkan para Imam Mazhab berbeda pendapat tentang suami istri yang bercerai sedangkan mereka mempunyai seorang anak atau lebih. ${ }^{9}$

Jika terjadi suatu halangan yang mencegahnya untuk melaksanakan hadhanah make hak hadhanah berpindah ke tangan orang lain dalam kerabat ibu garis lurus keatas. Apabila kerabat ibu dalam garis lurus ke atas herhalangan, maka yang lebih berhak adalah kerabat ayah dari anak tersebut, terutama kerabat dalam garis lurus ke atas. Jika anak yang masih kecil itu sama sekali tidak punya kerabat di

4 Amir Syarifudin, Hukum Perkawinan Islam di Indonesia antara Fiqih Munakahat dan UndangUndang Perkawinan, hal 328.

5 Tihami Dan Sahari Sahrani, Figh Munakahat: Kajian Fiqh Nikah Lengkap, (Jakarta: Rajawali Pers, 2010), cet. ke-7, hal, 217.

${ }^{6}$ Dalam hal terjadi perceraian acap kali yang menjadi permasalahan adalah siapakah yang lebih berhak untuk menjadi pemegang hadhanah yang bertanggung jawab atas perlindungan si anak. Seengketa seperti ini telah terjadi sejak zaman khalifah seperti kisah Umar bin Khattab yang dikutip oleh MA. Tihami dalam bukunya Fikih Munakahat bahwa Umar bin Khattab mempunyai seorang anak namanya Ashim bin Umar, kemudian ia bercerai. Pada suatu waktu Umar pergi ke Quba dan menemui anaknya itu sedang bermain-main di dalam masjid. Umar mengambil anaknya itu dan meletakkannya di atas kudanya. Pada saat itu datanglah ibu si anak, Umar berkata "anakku", wanita itu berkata "anakku". Maka kemudian dibawa perkara ini kepada Khalifah Abu Bakar dan Abu Bakar memberikan keputusan bahwa anak Umar tersebut ikut ibunnya dengan dasar yang dikemukakannya

7 An-Nawawi, Raudho al-Thalibin Wa Unda al-Muftin (Bairut : al-Maktab al-Islami), hal,. 303. Dan M. bin Ali asy-Syawkany, Nayl alAwthar min Asrar Muntaqa al Akhbar, Mesir, Idarat athThiba"eah al-Muniriyyah, $1344 \mathrm{H}$. Hal. 46

8 Syaikh Al-allamah Muhammad bin Abdurrahman ad-Dimasyqi, Fiqih Empat Mazhab, (Bandung : Hasyimi Press, 2004), hal. 416

${ }^{9}$ Muhammad Jawab Mughniyah, Fiqih Lima Mazhab, (Jakarta : Lentera, 1996),hal. 416 


\section{Hadhanah Dalam Prespektif Imam Madhab dan Kompilasi Hukum Islam serta Pengaruhnya Terhadap Pendidikan Anak}

antara muhrim-muhrimnya atau mempunyai kerabat tetapi tidak cakap bertindak untuk laksanakan hadhanah maka Pengadilan Agama depat nenetapkan siapa yang pantas menjadi ibu pengasuh dari anak-anak tersebut. ${ }^{10}$

Menurut pendapat Imam Hanafi dalam salah satu riwayatnya: Ibu lebih berhak atas anaknya hingga anak itu besar dan dapat berdiri sendiri dalam memenuhi keperluan sehari-hari seperti makan, minum, pakaian, beristinjak, dan berwudhu. Setelah itu, bapaknya lebih berhak memeliharanya. Untuk anak perempuan, ibu lebih berhak memeliharanya hingga ia dewasa, dan tidak diberi pilihan. Imam Miliki berkata: ibu lebih berhak memelihara anak perempuan hingga ia menikah dengan orang laki-laki dan disetubuhinya. Untuk anak laki-laki juga seperti itu, menurut pendapat Maliki yang masyhur, adalah hingga anak itu dewasa. Imam Syafi'i berkata: Ibu lebih berhak memeliharanya, baik anak itu laki-laki maupun perempuan, hingga ia berusia tujuh tahun. ${ }^{11}$ Apabila anak tersebut telah mencapai usia tujuh tahun maka anak tersebut diberi hak pilih untuk ikut diantara ayah atau ibunya. Imam Hambali dalam hal ini mempunyai dua riwayat: Pertama, ibu lebih berhak atas anak laki-laki sampai ia berumur tujuh tahun. Setelah itu, ia boleh memilih ikut bapaknya atau masih tetap bersama ibunya. Sedangkan untuk anak perempuan, setelah ia berumur tujuh tahun, ia terus tetap bersama ibunya, tidak boleh diberi pilihan. Kedua, seperti pendapatnya Imam Hanafi, yaitu ibu lebih berhak

10 Abdul Manan, PENERAPAN HUKUM ACARA PERDATA DI LINGKUNGAN PERADILAN AGAMA, Cet-8 (Jakarta : K E N C A N A, 2016) hal 445

${ }^{11}$ Syaikh Hasan Ayyub, Fiqih Keluarga,(Jakarta: Pustaka Al-Kautsar,2006),Cet V,hal. 207. 


\section{Mas'adah.}

atas anaknya hingga anak itu besar dan berdiri sendiri dalam memenuhi keperluan sehari-hari sepeti makan, minum, pakaian, beristinjak, dan berwudhu. Setelah itu, bapak lebih berhak memeliharanya. Untuk anak perempuan, ibu yang lebih berhak memeliharanya hingga ia dewasa dan tidak diberi pilihan. ${ }^{12}$

QS al Talaq : 6 “Tempatkanlah mereka (para isteri) di mana kamu bertempat tinggal menurut kemampuanmu dan janganlah kamu menyusahkan mereka untuk menyempitkan (hati) mereka. dan jika mereka (isteri-isteri yang sudah ditalaq) itu sedang hamil, Maka berikanlah kepada mereka nafkahnya hingga mereka bersalin, kemudian jika mereka menyusukan (anak-anak)mu untukmu Maka berikanlah kepada mereka upahnya, dan musyawarahkanlah di antara kamu (segala sesuatu) dengan baik; dan jika kamu menemui kesulitan Maka perempuan lain boleh menyusukan (anak itu) untuknya."13

Dan jika seorang ayah tersebut tidak mampu membayarkan kewajibanya tersebut, sehingga seorang isteri tidak mau mengasuh anak tersebut dikarenakan tidak adanya upah untuk merawat anak tersebut.Maka boleh ditanggung ahli waris kerabat yang terdekat yang mampu membayarkannya.Tetapi apabila ada orang lain yan dengan suka rela mendidik anak itu tanpa ongkos, maka hal tersebut dapat diserahkan kepada pendidik suka rela tersebut. ${ }^{14}$ Dengan demikian masa pembiayaan anak akan berakhir yakni bagi anak laki-laki apabila ia telah dewasa,

12 Syaikh Al-allamah Muhammad bin Abdurrahman ad-Dimasyqi, Fiqih Empat Mazhab, hal. 417 ${ }^{13}$ Mushaf al-Kamil, al-Qur"an dan terjemahnya, (Jakarta: Darus Sunnah, 2013)

${ }^{14}$ Kamal Muchtar, Asas-Asas Hukum Islam Tentang Perkawinan, (Jakarta: Bulan Bintang,1974), Cet I, hlm. 135. 


\section{Hadhanah Dalam Prespektif Imam Madhab dan Kompilasi Hukum Islam serta Pengaruhnya Terhadap Pendidikan Anak}

dapat bekerja dan nberdiri sendiri. Sedangkan bagi anak perempuan sampai ia kawin, ketika anak perempuan telah kawin maka nafkahnya menjadi tanggung jawab suaminya. ${ }^{15}$

\section{Masa Hadhanah}

Para ahli fiqih sepakat bahwa hak pemeliharaan anak adalah mulai bayi ketika baru dilahirkan sampai batas usia tamyiz, namun ada perbedaan pendapat mengenai kapan masa usia tamyiz tersebut. ${ }^{16}$ Masa hadhanah akan berhenti (habis) bila anak kecil tersebut sudah tidak lagi memerlukan pelayanan perempuan, telah dewasa, dan dapat berdiri sendiri, serta telah mampu untuk mengurus sendiri kebutuhan pokoknya, seperti makan sendiri, berpakaian sendiri, mandi sendiri. Dalam hal ini, tidak ada batasan tertentu tentang waktu habisnya. ${ }^{17}$ Imam Hanafi berpendapat bahwa "Masa hadhanah berakhir (habis) bilamana telah berumur tujuh tahun bagi laki-laki dan sembilan tahun kalau ia perempuan". Mereka menetapkan masa hadhanah perempuan lebih lama agar dia dapat menirukan kebiasaan-kebiasaan kewanitaannya dari hadhanah (ibu pengasuhnya). Menurut mazhab Syafie I tidak ada batasan tertentu bagi pemeliharaan atau asuhan terhadap anak Anak tetap tinggal bersama ibunya sampai ia dapat menentukan pilihan apakah tinggal bersama ibu

${ }^{15}$ Zahri Hamid, Pokok-Pokok Hukum Perkawinan Islam dan Undang-Undang Perkawinan di Indonesia, (Yogyakarta: Bina Cipta,1978), Cet.I, hlm. 106.

${ }^{16}$ Achmad Muhajir, "HadhanahDalam Islam (HakPengasuhan Anak DalamSektor Pendidikan Rumah)", Jurnal SAP Vol. 2 No. 2 Desember 2017, hal, 171-172

17 Sayyid Sabiq, Fiqih Sunnah, (Jakarta : Pena Pundi Aksara, 2004), hal 160 


\section{Mas'adah.}

atau ayahnya kalau si anak sudah sampai pada tingkat ini, dia disuruh memilih apakah tinggal bersama Ibu atau ayahnya, kalau seorang anak laki-laki memilih untuk tinggal bersama ibunya maka dia boleh tinggal bersama ibunya pada malam hari dan dengan ayahnya di siang harinya agar si ayah bisa mendidiknya, sedangkan bila si anak adalah anak perempauan dan memilih tinggal bersama ibunya, maka dia boleh tinggal bersama ibunya siang dan malam tetapi bila si anak memilih tinggal bersama ibu dan ayahnya maka dilakukan undian, bila si anak diam (tidak memberikan pilihan), dan ikut bersama ibunya.

Imam Malik berpendapat batas usia pemeliharaan anak laki-lakiadalah sampai mumayyiz, sedangkan ukuran mumayiz bagi laki-laki adalah tujuh tahun atau sudah ihtilam (mimpi/baligh). ${ }^{18}$ Sedangkan pada pada anak perempuan adalah sampai ia pada umur menikah. Menurut mazhab Hambali batas pemeliharaan atau pengasuhan baik anak laki-laki maupun perempuan adalah tujuan tahun. Jika anak tersebut telah mencapai usia tersebut dan ia seorang laki-laki, maka ia dipersilahkan untuk memilih di antara kedua orang tuanya, tetapi jika ia seorang wanita, maka ayahnya lebih berhak dengannya, dan tidak ada hak memilih baginya. ${ }^{19}$

\section{Syarat Pengasuh Hadhanah}

18 Syaikh Hasan Ayyub, Fiqih Keluarga, (Jakarta: Pustaka Al-Kautsar, 2006), H. 207

19 Ahmad Muhajir, Hadanah Dalam Islam (Hak Pengasuhan Anak dalam Sektor Pendidikan Rumah), (Jurnal SAP Vol. 2 No. 2 Desember 2017), H. 171 


\section{Hadhanah Dalam Prespektif Imam Madhab dan Kompilasi Hukum Islam serta Pengaruhnya Terhadap Pendidikan Anak}

Menurut mazhab Syafi'i, seseorang pengasuh itu mestilah memenuhi syaratsyarat berikut: 20

a. Islam ${ }^{21}$. Murtad atau kafir menjadi alasan gugurnya hak aasuh anak.

b. Sehat jasmani dan rohani. Orang gila tidak boleh menjadi pengasuh

c. Amanah. Ibu yang memiliki sifat khianat tidak berhak menjadi penjaga atau pengasuh, kerana dia tidak akan menjaga anak.

d. Baligh. Dalam mengasuh anak diperlukan kecakapan yang tidak bisa dilakukan oleh usia anak-anak..

e. Perempuan yang baik serta bermoral tinggi berakhlakul karimah. Perempuan fasik, seperti penzina, peminum arak, pencuri dan sebagainya tidak berhak menjadi pengasuh.

f. Merdeka. Hamba tidak berhak menjadi pengasuh anak

g. Tinggal bersama kanak-kanak yang diasuh

h. Jika pengasuh itu ibunya sendiri, disyaratkan dia belum kawin lagi dengan lelaki lain kecuali kalau kawin dengan laki-laki yang memiliki hubungan muhrim dengan anaknya.

${ }^{20}$ Ibnu Mas`ud dan Zainal Abidin S, Fiqih Madzhab Syafi`i Edisi Lengkap Muamalat, Munakahat, Jinayat, (Bandung: CV. Pustaka Setia, 2000), H. 418

21 Mengenai syarat harusnya beragama Islam bagi hadhin maupun hadhinah, terdapat perbedaan pendapat ulama mengenai hal ini. Namun, jumhur ulama' sepakat bahwa anak kecil muslim tidak boleh diasuh oleh pengasuh yang bukan muslim. Hal ini karena orang kafir tidak mempunyai kuasa atas orang muslim. Selain itu juga ditakutkan terhadap pengafiran anak tersebut Lihat Mochammad Firdaus, Skripsi: "Tinjauan Maslahah Mursalah Terhadap Hadhanah Ibu Murtad", (Semarang, UIN Walisongo Semarang, 2016), hlm. 32 


\section{Mas'adah.}

i. Mempunyai tempat tinggal karena tempat tinggal adalah suatu yang urgen dalam sebuah pengasuhan.

j. Jika pengasuh kanak-kanak merupakan seorang wanita asing, disyaratkan suaminya mestilah mempunyai pertalian saudara dengan anak yang di asuh.

Menurut Mazhab Hanbali22 yang dikutip dalam Fiqih sunnah mengatakan antara syarat-syarat penjaga adalah seperti berikut:

a. Islam.

b. Berakal yaitu tidak gila dan tidak $m a^{\prime} t u h$.

c. Tidak fasik.

d. Merdeka

e. Tidak buta atau kurang penglihatan.

f. Tidak mengidap penyakit menular. ${ }^{23}$ seperti sopak atau kusta.

g. Penjaga tidak menikah dengan lelaki lain yang tiada mempunyai hubungan kekeluargaan dengan anak itu. Jika penjaga itu menikah dengan saudara

${ }^{22}$ Wahbah Zuhaily, dalam bukunya Figh Islam Wa Adillatuhu, ia menyebutkan pengasuh anak yaitu:

Syarat khusus untuk pengasuh wanita atau ibu adalah:

1) Wanita itu tidak menikah kembali dengan laki-laki lain. Hal ini sejalan dengan hadits

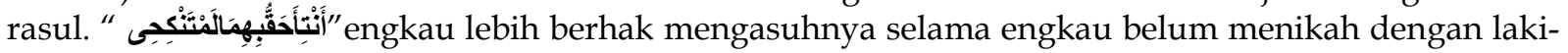
laki lain".

2) Wanita itu harus memiliki hubungan mahram dengan anak yang dipeliharanya.

3) Wanita itu tidak pernah berhenti meskipun tidak diberi upah. Wanita tidak dapat mengasuh anak-anak dengan sikap yang tidak baik, seperti pemarah, orang yang dibenci oleh anak tersebut atau membenci anak-anak. Lihat Wahbah al-Zuhaili, Figh al-Islam wa Adillatuhu, (Jakarta: Gema Insani, 2011), cet. ke-1, h. 68-69.

${ }^{23}$ Satria Effendi M Zein, Problematika Hukum Keluarga Islam Kontemporer, ( Jakarta: Kencana, 2005), h 172. 


\section{Hadhanah Dalam Prespektif Imam Madhab dan Kompilasi Hukum Islam serta Pengaruhnya Terhadap Pendidikan Anak}

terdekat kepada anak tersebut, maka ibu kepada anak itu berhak memeliharanya ${ }^{24}$

Menurut pendapat Mazhab Hanafi ${ }^{25}$ yang dikutip dari buku hukum-hukum fiqih Islam berpendapat bahawa syarat-syarat penjaga hadanah adalah apabila dia seorang lelaki atau seorang perempuan adalah seperti berikut:

a. Berakal. Penjaga yang gila tidak boleh menjadi penjaga walaupun dia waras untuk sebentar saja.

b. Berkuasa untuk melakukan kerja. Orang yang sudah tua atau lanjut umur, orang buta, bisu, pekak dan orang yang sentiasa sakit tidak boleh menjadi penjaga.

c. Sekiranya anak yang dipelihara itu perempuan, maka penjaganya mestilah berkuasa mengawasi dan menjaga kanak-kanak itu daripada melakukan sifatsifat buruk khususnya perbuatan-perbuatan yang didorong oleh nafsu dan syahwat. Jika penjaga tidak sanggup untuk menghalang dan mencegah anak itu daripada melakukan sifat-sifat buruk yang disebutkan, maka lebih baik penjaga mengundurkan diri.

d. Penjaga mestilah seorang yang amanah kepada agama, bukan peminum arak atau penzina.

e. Penjaga mestilah seorang yang sihat daripada semua penyakit yang berjangkit seperti sopak atau kusta. 


\section{Mas'adah.}

f. Penjaga mestilah seorang yang cerdik dalam pengurusan harta dan bukan seorang yang pembazir.

g. Jika penjaga itu wanita, maka disyariatkan dia bukanlah seorang yang sering didatangi lelaki asing, kecuali jika wanita berkahwin dengan mahram anak itu. Jika penjaga sering didatangi oleh lelaki asing, maka haknya sebagai penjaga akan gugur.

Menurut Madzhab Maliki Syarat pengasuh hadanah adalah26 :

a. Tidak mensyaratkan pengasuh harus seorang muslimah, jika anak tersebut juga wanita. Alasan mereka adalah sebuah riwayat yang menyatakan bahwa Rasulullah SAW, menyuruh memilih kepada anak untuk berada dibawah asuhan ayahnya yang muslim atau pada ibunya yang musyrik, tetapi anak itu memilih ibunya, lalu Rasulullah SAW bersabda: "Ya Allah, tunjuki anak itu, condongkan hatinya kepada ayahnya". (HR. Abu Dawud). Tapi apabila dikhawatirkan pengasuh yang bukan muslim tersebut memberi makan dengan makanan haram, maka pengasuh itu diawasi oleh orang islam. ${ }^{27}$

b. Berakal sehat dan cerdas. Bagi orang yang kurang sehat akalnya atau gila, tidak boleh menangani hadhanah karena mereka tidak dapat mengurusi dirinya sendiri, maka ia tidak boleh diserahi mengurusi orang lain. Seseorang yang

${ }_{27}$ Maulina Syahfitri, Batas Masa Hadanah (Studi Analisis Menurut Pendapat Mazhab Maliki), (Skripsi, UIN Ar-Raniry Darussalam Banda Aceh, 2016), hal. 26 


\section{Hadhanah Dalam Prespektif Imam Madhab dan Kompilasi Hukum Islam serta Pengaruhnya Terhadap Pendidikan Anak}

tidak memiliki apa - apa tentu ia tidak dapat memberi sesuatupun kepada orang lain. ${ }^{28}$ Bahkan Imam Malik menambahnya dengan Cerdas.

\section{Ketentuan Hadhanah Menurut Kompilasi Hukum Islam}

Pada Mulanya Pada mulanya memang pembagian hak hadhanah ini di dasarkan pada sistem kekerabatan tersebut. Pada masyarakat patrilineal, anak-anak yang lahir dari perkawinan ini mendapat garis keturunan dari ayahnya, sementara dengan ibunya hanya mendapat hubungan sosial dan moral saja, bukan hubungan hukum. Sehingga apabila terjadi pembubaran perkawinan karena kematian atau karena perceraian maka kedudukan anak tetap berada dalam kekerabatan ayah, dan yang bertanggung jawab atas semua biaya pemeliharaan dan pendidikan anak adalah ayah kandungnya atau semua kerabat laki-laki dari ayah kandungnya. ${ }^{29}$ setelah adanya Undang-undang Perkawinan Nomor 1 Tahun 1974 tentang Perkawinan ini tidak memperjelas atau tidak mengatur dengan tegas tentang ketentuan hak asuh anak jika terjadi perceraian siapa antara bapak atau ibu yang diberi hak untuk mengasuh anak.

Sebagaimana menurut Mukhtar Zamzami bahwa ketentuan hak asuh anak dalam UU No. 1 Tahun 1974 Tentang Perkawinan tersebut telah menggeser ketentuan yang sudah mapan sebelumnya yaitu sistem matrilineal atau patrilineal, dimana yang berhak dan mempuyai tanggungjawab terhadap pemeliharaan anak

\footnotetext{
174.

${ }^{28}$ Slamet Abidin dan Aminuddin, Fikih Munakahat 2, (Bandung : CV Pustaka Setia, 1999), Hal.

${ }^{29}$ Hilman Hadikusuma (Haji), Hukum perkawinan adat (Bandung : Citra Aditya Bakti, 2003) H. 139.
} 


\section{Mas'adah.}

adalah ayah atau ibunya sesuai sistem yang dianut di atas.30 Dengan diundangkannya UU Perkawinan terlebih lagi Kompilasi Hukum Islam (KHI), jika terjadi perselisihan hak hadhanah pasca perceraian, maka bisa ditentukan dengan memilih pengasuh yang memenuhi syarat dan ketentuan untuk melakukan pengasuhan tersebut sesuai dengan ketentuan yang berlaku. ${ }^{31}$

Pada umumnya ahli fikih mensyaratkan hak pengasuhan anak kepada orang tua yang Muslim. Kompilasi Hukum Islam Pasal 172 menentukan bahwa anak yang masih di bawah umur, mereka beragama menurut ayahnya atau lingkungannya.32 Pemeliharaan anak/hadhanah adalah kegiatan mengasuh, memelihara, dan mendidik anak-anak mereka hingga dewasa atau dapat berdiri sendiri (Pasal 1 huruf g KHI). Islam mengatur ketentuan mengenai Hadanah33 ini dalam beberapa pasal. Apabila terjadi perceraian antara suami istri maka menurut pasal $105 \mathrm{KHI}$ adalah :

a. Pemeliharaan anak yang belum mumayyiz atau belum berumur 12 tahun adalah hak ibunya

${ }^{30}$ Mukhtar Zamzami, Perempuan dan Keadilan dalam Hukum Kewarisan Indonesia, (Jakarta: Prenada Media Group, 2013), H. 186.

${ }^{31}$ Satria Efendi M. Zein, Problematika Hukum Keluarga Islam Kontemporer, (Jakarta :Kencana, 2004), H. 169.

32 Syarif Mappiasse, Logika Hukum Peertimbangan Putusan Hakim, (Jakarta : Prenamedia Group, 2015) hlm 130

${ }^{33}$ kedua orang tua bercerai, bila tidak memperselisihkan pemeliharaan anak maka, baik ibu atau bapak tetap berkewajiban memelihara dan mendidik anak-anaknya semata-mata berdasarkan kepentingan terbaik bagi anak. Bapak bertanggung jawab atas semua biaya pemeliharaan anak, bilamana bapak tidak mempunyai kesanggupan untuk itu maka ibu turut bertanggung jawab 


\section{Hadhanah Dalam Prespektif Imam Madhab dan Kompilasi Hukum Islam serta Pengaruhnya Terhadap Pendidikan Anak}

b. Pemeliharaan anak yang sudah mumayyiz diserahkan kepada anak untuk memilih diantara ayah atau ibunya sebagai pemegang hak pemeliharaanya;

c. Biaya pemeliharaan ditanggung oleh ayahnya. Atas dasar pasal di atas penguasaan anak akibat perceraian bagi anak yang belum mumayyiz atau belum berumur 12 tahun jatuh ke asuhan ibunya. Akan tetapi setelah umur 12 tahun, anak diberi kekuasaan untuk memilih kepada siapa akan tinggal.

Adapun jika pihak ibu tidak ada atau meninggal maka kekuasaan atas anak telah diatur sesuai pasal 156 sebagai berikut :

a. Anak yang belum mumayyiz berhak mendapatkan hadhanah dari ibunya ${ }^{34}$, kecuali bila ibunya telah meninggal dunia, maka kedudukannya digantikan oleh:

1) Wanita-wanita dalam garis lurus ke atas dari ibu;

2) Ayah;

3) Wanita-wanita dalam garis lurus ke atas dari ayah;

4) Saudara perempuan dari anak yang bersangkutan;

5) Wanita-wanita kerabat sedarah menurut garis samping dari ayah.

b. Anak yang sudah mumayyiz berhak memilih untuk mendapatkan hadhanah dari ayahatau ibunya;

${ }^{34}$ T. M Hasby ash-Shiddieqy, Hukum Antar Golongan, (Semarang: PT. Pustaka Rizki Putra, 1987), cet. ke-4, hal. 111. 


\section{Mas'adah.}

c. Apabila pemegang hadhanah ternyata tidak dapat menjamin keselamatan jasmanidan rohanianak, meskipun biaya nafkah dan hadhanah telah dicukupi, maka atas permintaann kerabat yang bersangkutan Pengadilan Agama dapat memindahkan hak hadhanah kepada kerabat lain yang mempunyai hak hadhanah pula;

d. Semua biaya hadhanah dan nafkah anak menjadi tanggung jawab ayah menurut kemampuannya,sekurang-kurangnya sampai anak tersebut dewasa dapat mengurus diri sendiri (21 tahun)

e. Bilamana terjadi perselisihan mengenai hadhanah dan nafkah anak, Pengadilan Agama memberikan putusannya berdasrkan huruf (1),(2), dan (3);

f. Pengadilan dapat pula dengan mengingat kemampuan ayahnya menetapkan jumlah biaya untuk pemeliharaan dan pendidikan anak-anak yang tidak turut padanya.

Dalam Undang-Undang Nomor 1 Tahun 1974 tentang Perkawinan pasal 42-45 dijelaskan bahwa orang tua wajib memelihara dan mendidik anak-anaknya yang belum mencapai umur 13 tahun dengan cara yang baik sampai anak itu kawin atau dapat berdiri sendiri. Kewajiban ini berlaku terus meskipun orang tua si anak putus karena perceraian atau kematian.Kekuasaan orang tua juga meliputi untuk mewakili anak tersebut mengenai segala perbuatan hukum di dalam dan diluar Pengadilan. Kewajiban orang tua memelihara anak meliputi pengawasan (menjaga keselamatan jasmani dan rohani), pelayanan (memberi dan menanamkan kasih sayang) dan 


\section{Hadhanah Dalam Prespektif Imam Madhab dan Kompilasi Hukum Islam serta Pengaruhnya Terhadap Pendidikan Anak}

pembelajaran dalam arti yang luas yaitu kebutuhan primer dan sekunder sesuai dengan kebutuhan dan tingkat sosial ekonomi orang tua si anak. Ketentuan ini sama dengan konsep hadhanah dalam hukum Islam, dimana dikemukakan bahwa orang tua berkewajiban memelihara anak-anaknya, semaksimal mungkin dengan sebaikbaiknya. ${ }^{35}$

Adapun jika pihak ibu tidak ada atau meninggal maka kekuasaan atas anak telah diatur sesuai pasal 156 sebagai berikut :

a. Anak yang belum mumayyiz berhak mendapatkan hadhanah dan ibunya, kecuali bila ibunya telah meninggal dunia, maka kedudukannya digantikan oleh:

1) Wanita-wanita dalam garis lurus ke atas dari ibu;

2) Ayah;

3) Wanita-wanita dalam garis lurus ke atas dari ayah;

4) Saudara perempuan dari anak yang bersangkutan;

5) Wanita-wanita kerabat sedarah menurut garis samping dari ayah.

b. Anak yang sudah mumayyiz berhak memilih untuk mendapatkan hadhanah dari ayahatau ibunya;

c. Apabila pemegang hadhanah ternyata tidak dapat menjamin keselamatan jasmanidan rohanianak, meskipun biaya nafkah dan hadhanah telah dicukupi,

${ }^{35}$ Abdul Manan, Penerapan Hukum Acara Perdata di Lingkungan Peradilan Agama, (Jakarta: Kencana, 2008), hal.428-429. 


\section{Mas'adah.}

maka atas permintaann kerabat yang bersangkutan Pengadilan Agama dapat memindahkan hak hadhanah kepada kerabat lain yang mempunyai hak hadhanah pula;

d. Semua biaya hadhanah dan nafkah anak menjadi tanggung jawab ayah menurut kemampuannya,sekurang-kurangnya sampai anak tersebut dewasa dapat mengurus diri sendiri (21 tahun)

e. Bilamana terjadi perselisihan mengenai hadhanah dan nafkah anak, Pengadilan Agama memberikan putusannya berdasarkan huruf (a),(b), dan (c);

f. Pengadilan dapat pula dengan mengingat kemampuan ayahnya menetapkan jumlah biaya untuk pemeliharaan dan pendidikan anak-anak yang tidak turut padanya.

\section{Pengaruh Hadhanah terhadap Pendidikan Anak}

Pendidikan merupakan salah satu hak asasi manusia yang merupakan bagian dari hak ekonomi, sosial dan budaya. Begitupun dengan seorang anak, ia berhak memperoleh pendidikan yang layak dari orang tuanya. Pola hadhanah sangat berpengaruh terhadap pendidikan seorang anak. Rumah merupakan bagian yang tidak bisa dipisahkan dari pendidikan karena bermula dari rumah setiap manusia mendapatkan pendidikan awal.Tentunya pendidikan secara rill yang diberikan oleh pendidik yaitu orangtua dalam bentuk pengasuhan (mendidik).

Tujuan dari pemeliharaan anak yang begitu luhur dan mulia tentunya akan sulit tercapai bila pelaksanaannya dilakukan secara sembarangan oleh pihak yang 


\section{Hadhanah Dalam Prespektif Imam Madhab dan Kompilasi Hukum Islam serta Pengaruhnya Terhadap Pendidikan Anak}

kurang layak ${ }^{36}$. Oleh karenanya persyaratan tertentu sebagai standar dalam menentukan pemegang hak pemeliharaan anak. Persyaratan yang diajukan oleh Imam Taqiyuddin, bahwa pemelihara atau pengasuh harus: Berakal sehat, merdeka, memiliki kasih sayang, dapat dipercaya, tidak bersuami, beragama Islam, dan bertempat tinggal ${ }^{37}$. Mengenai syarat bagi pemegang hak hadhanah ini bahkan ada yang mensyaratkan harus mempunyai kafa'ah atau martabat yang sepadan dengan kedudukan si anak ${ }^{38}$.Maksudnya agar pengasuh dapat memberikan pendidikan yang layak bagi si anak agar keadaan anak itu bertambah baik dari segi jiwa dan raga si anak.

Pendidikan rumah merupakan gerbang utama untuk menghasilkan peserta didik yang baik.Dan orangtua lah sebagai pendidik yang bertanggung jawab atas pendidikan anak, terlebih ibu merupakan pendidik anak yang sangat berpengaruh dalam perkembangan pertumbuhan dan pendidikan bagi anak.Oleh karnanya ibu diberikan prioritas atas pengasuhan anak jika terjadi perpisahan/talak dalam berumah tangga. 39

${ }^{36}$ Hendaknya para pihak yang ingin melangsungkan perkawinan terlebih dahulu mengetahui pengetahuan tentang hak dan kewajiban yang harus diemban sebagai seorang suami-istri perihal peran dan tanggung jawabnya sebagai orang tua dari anak-anak tersebut, serta kepada kedua orang tua sebaiknya mempertimbangkan dari pada akibat perceraian yang akhirnya menjadi beban bagi anak-anak mereka lihat DR. Maidin, Gultom, S.H., M.Hum., Perlindungan Hukum Terhadap Anak dalam Sistem Peradilan Pidana Anak di Indonesia, (Bandung: PT Refika Aditama, 2008), hal. 33

${ }^{37}$ I. T. Abu Bakr, Kifayah al-ahyar, Surabaya : Al-Hidayah 1989

38S. T. Al-Hamdani, Risalah al-Nikah (Terj), Penerjemah: Agus Salim, Jakarta, Pustaka Amani,

39 Ahmad Muhajir, "Hak Pengasuhan Anak dalam Sektor Pendidikan Rumah". Hadhanah Dalam Islam,Vol.2 No.2, Desember 2017, 172. 


\section{Mas'adah.}

Penguatan pola asuh dalam keluarga Islam diprioritaskan pada ibu-ibu, karena ibu merupakan soko guru keluarga dalam mendidik putra-putrinya. Dalam konteks sosiologi keluarga patrilinial membagi tugas dan peran antara ibu dan bapak dalam keluarga. orang tua dalam pendidikan anak, jelas dan tegas bahwa mereka adalah pendidik yang utama dan pertama karena merekalah yang memberikan pengajaran, pendidikan, apapun itu untuk perdana kalinya yang memberikan arah dan pengaruh akan menjadi apa. Tugas bapak (ayah) adalah bertanggungjawab mencari nafkah untuk menghidupi dan mencukupi semua kebutuhan rumah tangga oleh karena itu aktifitasnya tidak hanya ada dalam internal keluarga, akan tetapi lebih banyak di luar rumah dalam rangka mencari untuk mendapatkan penghasilan. Keterbatasan waktu yang dimiliki oleh bapak (ayah) tersebut maka sangat memungkinkan untuk berbagi peran dengan ibu ${ }^{40}$.Tugas pokok ibu adalah memberikan layanan pengasuhan baik peningatan pertumbuhan fisik (tugas-tugas pertumbuhan) atau fungsi organ fisik secara maksimal, dan juga layanan pengasuhan untuk bimbingan, pengarahan, dan pembentukan kepribadian (mental emosional) pada anak ${ }^{41}$.

Orang tua wajib menitipkan putra putrinya ke Lembaga pendidikan untuk membantu bukan mengambil alih pendidikan ${ }^{42}$.karena keterbatasan waktu dan skill.

40 I Nyoman Sujana, Akibat-Akibat Hukum Perceraian Dalam PerkawinanCampuran, 2017, (Jurnal Notariil, Vol. 1, No. 2, Mei 2017), H. 58-67.

41Saiful Hadi, "Penguatan Peran Keluarga Jamaah Masjid Baitul Abror Teja Timur".Pola Pengasuhan Islami Dalam Pendidikan Keluarga, Volume 12, Nomor 1, Juni 2017, 121.

${ }^{42}$ Susy Haryawan, "Peran Orang Tua Dalam Pendidikan 


\section{Hadhanah Dalam Prespektif Imam Madhab dan Kompilasi Hukum Islam serta Pengaruhnya Terhadap Pendidikan Anak}

guru yang memang professional dengan bidangnya. Namun demikian, orang tua tidak bisa kemudian lepas tangan dengan alasan tidak memiliki bekal pendidikan dan telah membayar tempat sekolah tersebut. Terkadang adanya anak yang putus sekolah atau bahkan tidak bersekolah diduga erat kaitannya dengan pemahaman orang tua tentang pendidikan, atau bahkan karena mejadi korban dari perpisahan orang tuanya, termasuk juga pola pendidikan yang diterapkan.Pola asuh merupakan hal yang fundamental dalam pembentukan karakter.Teladan sikap orang tua sangat dibutuhkan bagi perkembangan anak-anak, karena anak -anak melakukan modeling dan imitasi dari lingkungan terdekatnya.Keterbukaan antara orang tua dan anak menjadi hal penting agar dapat menghindarkan anak dari pengaruh negatif yang ada di luar lingkungan keluarga. Maka dari itu orang tua perlu membantu anak dalam mendisiplinkan diri43.

Perceraian baik yang disebabkan kematian salah satu pihak atau talak, fasakh, atau li'an, akan menimbulkan akibat bagi penyelenggaraan "pemeliharaan anak". Dalam pemeliharaan anak akan menyangkut beberapa hak. Dari sisi anak kecil, ia mempunyai hak untuk tetap hidup dan tumbuh ${ }^{44}$. Dari sisi pengasuh ia memiliki hak

Anak",https://www.kompasiana.com/paulodenoven/5a667237cbe5237e6c208d03/peranorang-tua-dalam-pendidikan-anak\# (diakses pada 6 Juni 2020, pukul 9:57)

${ }^{43}$ Rabiatul Adawiah, "Studi pada Masyarakat Dayak di Kecamatan Halong Kabupaten Balangan".Pola Asuh Orang Tua dan Implikasinya terhadap Pendidikan Anak, Volume 7, Nomor 1, Mei 2017, 34.

44 , ada beberapa kebutuhan utama anak yang penting untuk dipenuhi yaitu

a) Kebutuhan akan adanya kasih sayang.

b) Kebutuhan akan keikutsertaan dan diterima dalam kelompok.

c) Kebutuhan untuk diri sendiri.

d) Kebutuhan untuk prestasi.

e) Kebutuhan akan pengakuan dari orang lain. 


\section{Mas'adah.}

untuk mendidik anak yang diasuh dan dipeliharanya. Sedangkan dari sisi pemeliharaan jiwa insani, hadhanah berupa hak masyarakat untuk memberi kehidupan bagi jiwa manusia dan memeliharanya.Yang terakhir ini disebut dengan hak Allah SWT45. Jadi, pada intinya pengaruh pola hadhanah (pemeliharaan anak) sangat berpengaruh terhadap perkembangan pendidikan si anak tersebut.Apalagi jika kedua orang tua anak tersebut bercerai maka jangan sampai pendidikan si anak bisa terbengkalai dan pada akhirnya menyebabkan anak itu putus sekolah sampai terjerumus kedalam pergaulan bebas karena kurangnya kasih sayang dan pola asuh yang baik dari kedua orang tuannya.

\section{KESIMPULAN}

Dari Perceraian menimbulkan hadhanah terhadap anak di bawah umur sampai anak itu tidak lagi memerlukan penjagaan dan dapat mengurus keperluannya sehari-hari, seperti makan, minum, mengatur pakaian, dan lain sebagainya. Sedangkan untuk perempuan berakhir apabila sudah baligh atau telah datang haid pertama.Sedangkan pengikut pada generasi akhir menetapkan bahwa masa Hadhanah itu berakhir umur 19 tahun bagi anak laki-laki. Dan 11 tahun umtuk seorang perempuan.

f) Kebutuhan untuk dihargai.

g) Kebutuhan untuk memperoleh palsafah hidup yang utuh lihat Anjani Sipahutar, "Tanggung Jawab Orang Tua Terhadap Nafkah Anak Pasca Putusan Perceraian Bagi Warga Negara Indonesia Yang Beragama Islam". USU Law Journal, Vol.4.No.1 Januari 2016. 161

45 Ahmad Muhajir, "Hak Pengasuhan Anak dalam Sektor Pendidikan Rumah". Hadhanah Dalam Islam,Vol.2 No.2, Desember 2017, 169. 


\section{Hadhanah Dalam Prespektif Imam Madhab dan Kompilasi Hukum Islam serta Pengaruhnya Terhadap Pendidikan Anak}

Apabila perceraian terjadi antara suami istri yang telah berketurunan, yang berhak mengasuh anak pada dasarnya adalah istri, ibu anak-anak. Karena wanita lebih mampu dari laki-laki untuk mengurus anak kecil dan memeliharanya dalam usia sekian itu, dan juga lebih lemah lembut dan lebih sabar, lebih tekun dan lebih banyak waktunya. Ulama juga sepakat jika terjadi perceraian yangberhak mendapatkan hak asuh anak adalah ibu. Ibu berhak mendapat hak asuh anak dikarenakan ikatan batin antara anak dengan ibu lebih kuat dan sentuhan tangan keibuan yang lazimnya dimiliki oleh ibu akan lebih menjamin pertumbuhan mentalitas anak secara lebih baik apabila dibandingkan anak diasuh oleh bapak. Jadi, selama ibu tidak ada halangan untuk mengasuh anaknya, ibulah yang lebih berhak mendapatkan hak asuh anak.

\section{E. DAFTAR PUSTAKA}

Abidin, Slamet dan Aminuddin, Fikih Munakahat 2, Bandung : CV Pustaka Setia, 1999

Ad Dimasyqi, Syaikh Al-allamah Muhammad bin Abdurrahman, Fiqih Empat Mazhab, Bandung : Hasyimi Press, 2004

Alam, Andi Samsu dan M. Fauzan, Hukum Pengangkatan Anak Prespektif Islam, (Jakarta: Kencana, 2008

Al Amir, Muhammad bin Ismail Subulus Salam Syarah Bulughul Maram Jilid III Jakarta: Darus Sunnah, 2012

Al Dardiri, Abi al-Barakat Ahmad Ibn Muhammad Ibn Ahmad, Asy Syarhush Shaghiir 'ala Aqrab al-Masalik Ila Mazhab al-Imam Malik, Kairo: Dar alMaarif, tt. 


\section{Mas'adah.}

Al Hamdani, Said bin Abdullah bin Thalib, Risalah al-Nikah (Terj), Penerjemah: Agus Salim, Jakarta, Pustaka Amani, 1989.

Al Jamal, Ibrahim Muhammad Al-Jamal, Fiqih Muslimah,

Al Kamil, Mushaf, al-Qurean dan terjemahnya, Jakarta: Darus Sunnah, 2013

Al Zuhayli, Wahbah, Fiqh al-Islam wa Adillatuhu, Cet. 1, Jakarta: Gema Insani, 2011

An-Nawawi, Raudho al-Thalibin Wa Unda al-Muftin Bairut : al-Maktab alIslami, tt.

Anshari, AbuYahya Zakaria, Fathul Wahab, Juz II, Beirut: Dar al-Kutub, 1997

ash-Shiddieqy, T. M Hasby, Hukum Antar Golongan, Cet. 4, Semarang: PT. Pustaka Rizki Putra, 1987.

Asy syawkany, Muhammad bin Ali, Nayl alAwthar min AsrarMuntaqa alAkhbar,

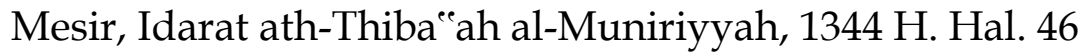

Ayyub, Syaikh Hasan Ayyub, Fiqih Keluarga, Jakarta: Pustaka Al-Kautsar, 2006

Burhanudin TR, “Pendidikan Keluarga”, Jurnal Universitas Pendidikan Indonesia, tt.

Elimartati, dan Firdaus, "Hak Hadhanah dalam Putusan Pengadilan Agama”, Jurnal Ilmiah Syari'ah, Volume 17, Nomor 2, Juli-Desember 2018,

Firdaus, Mochammad, Skripsi: “Tinjauan Maslahah Mursalah Terhadap Hadhanah Ibu Murtad",Semarang, UIN Walisongo Semarang, 2016

Ghanim, Ahmad, Al-Fawakih Ad-Dawani, Jilid 2, Beirut : Daar Al-Kutub AlIlmiyah, $1418 \mathrm{H}$ 


\section{Hadhanah Dalam Prespektif Imam Madhab dan Kompilasi Hukum Islam serta Pengaruhnya Terhadap Pendidikan Anak}

Ghazaly, Abdul Rahman, ,Fiqih Muna\&ahat, Jakarta:Prenada Media 2013

Gultom, DR. Maidin, S.H., M.Hum., Perlindungan Hukum Terhadap Anak dalam Sistem Peradilan Pidana Anak di Indonesia, Bandung: PT Refika Aditama, 2008

Hadikusuma (Haji), Hilman, Hukum perkawinan adat Bandung : Citra Aditya Bakti, 2003

Hadi, Saiful, "Penguatan Peran Keluarga Jamaah Masjid Baitul Abror Teja Timur".Pola Pengasuhan Islami Dalam Pendidikan Keluarga, Volume 12, Nomor 1, Juni 2017, 121.

Hamid, Zahri, Pokok-Pokok Hukum Perkawinan Islam dan Undang-Undang Perkawinan di Indonesia, Cet.I, Yogyakarta: Bina Cipta,1978,

Haryawan, Susy “Peran Orang Tua Dalam Pendidikan Anak", dalam https://www.kompasiana.com/paulodenoven/5a667237cbe5237e6c208d0 3/peran-orang-tua-dalam-pendidikan-anak\# (diakses pada 6 Juni 2020, pukul 9:57)

Kementrian Wakaf dan Urusan Agama Kuwait, mausu'ah fiqhiyah, Kuwait : Wizaaratul Awqaf Wa As-Syu'un Al-Islamiyah, 1404 H, jilid 17

Kurniawati, Vivi, Lc., Pengasuhan Anak, (Lentera Islam),

Mahfudz,Sahl,: Solusi Problematika Umat,Surabaya: LTN NU Jawa Timur, 2003

Manan, Abdul, Penetapan Hukum Acara Perdata Di Lingkungan Peradilan Agama, Cet-8, Jakarta : Kencana, 2016

Mappiasse, Syarif, Logika Hukum Peertimbangan Putusan Hakim, Jakarta : Prenamedia Group, 2015 


\section{Mas'adah.}

Mas'ud, Ibnu dan Zainal Abidin S, Fiqih Madzhab Syafi i Edisi Lengkap Muamalat, Munakahat, Jinayat, Bandung: CV. Pustaka Setia, 2000

Muchtar, Kamal, Asas-Asas Hukum Islam Tentang Perkawinan, Cet.1., Jakarta: Bulan Bintang,1974.

Mughniyah, Muhammad Jawad, Fiqih Lima Mazhab, Jakarta : Lentera, 1996

Muhajir, Ahmad Muhajir,"Hak Pengasuhan Anak dalam Sektor Pendidikan Rumah".Hadhanah Dalam Islam,Vol.2 No.2, Desember 2017

M. Zein, Satria Effendi, Problematika Hukum Keluarga Islam Kontemporer, ( Jakarta: Kencana, 2005

Nasution, Harun dkk, Ed, Ensiklopedi Islam Indonesia ,Jakarta:Djambatan,1992

Prodjohamidjodjo, Martiman, Hukum Perkawinan Indonesia, Jakarta: Indonesia Legal Center Publishing, 2002

Sabiq Sayyid, Fiqih Sunnah, Jilid 2, Jakarta: Pena Pundi Aksara,2007

Sujana, I Nyoman, Akibat-Akibat Hukum Perceraian Dalam PerkawinanCampuran, 2017, Jurnal Notariil, Vol. 1, No. 2, Mei 2017

Syahfitri, Maulina, Batas Masa Hadanah (Studi Analisis Menurut Pendapat Mazhab Maliki, Skripsi, UIN Ar-Raniry Darussalam Banda Aceh, 2016

Syarifudin, Amir, HukumPerkawinan Islam di Indonesia antara Fiqih Munakahat dan Undang-Undang Perkawinan, Ttp,tp,tt.

Tihami Dan Sahari Sahrani, Fiqh Munakahat: Kajian Fiqh Nikah Lengkap, Jakarta: Rajawali Pers, 2010 cet. ke-7,

Zamzami, Mukhtar, Perempuan dan Keadilan dalam Hukum Kewarisan Indonesia, (Jakarta: Prenada Media Group, 2013. 